\title{
Suspect's access to a lawyer at an early stage of criminal proceedings in view the case-law of the European Court of Human Rights
}

\author{
Direito do imputado à defesa técnica nas etapas \\ iniciais da persecução penal na perspectiva da \\ Corte Europeia de Direitos Humanos
}

\section{Andrzej Sakowicz ${ }^{1}$}

University of Bialystok, Poland sakowicz@uwb.edu.pl

http://orcid.org/0000-0001-6599-4876

\begin{abstract}
AвSTRACT: Access to a lawyer at the pre-trial stage of proceedings is an essential component of the right to defense in criminal proceedings and the right to a fair trial. Access to a lawyer enables the accused to make a good decision for his her defence. At present, there is no doubt that prompt access to a lawyer constitutes an important counterweight to the vulnerability of suspects in police custody, ensures equality of arms and provides a fundamental safeguard against coercion. This study analyses a suspect's right to access to a lawyer at the initial stage of criminal proceedings in the case law of the European Court of Human Rights. The first part of the article provides an analysis of the understanding of the right to a lawyer at the pre-trial stage as applied by the ECtHR prior to the Salduz case. This period in the ECtHR's case law was characterized by a lack of precision as to the temporal limits of the right laid down in Article $6 \S 3$ (c) of the ECHR. The next part shows the changes brought about by the judgment in the Salduz case regarding the protection of suspects and ensuring their right to counsel. It is argued that the Salduz doctrine not only covered the suspect's access to a lawyer at the initial stage of the pre-trial proceedings, but also stressed the obligation to inform the suspect of his or her rights, including the right to remain silent.
\end{abstract}

1 Professor at the University of Bialystok, Poland; the Faculty of Law; the Department of Criminal Procedure. 
An important element of the Salduz doctrine was the possibility to eliminate evidence obtained during an interrogation conducted at an early stage of the pre-trial proceedings in the absence of a defense counsel. Further, the paper argues that the standard set out in the judgment in the Salduz v. Turkey case was confirmed in a number of rulings. The fourth part of the paper draws attention to the erosion of the Salduz standard that occurred with the judgment in the Ibrahim and Others v. the UK case. The article also brings into focus recent judgments of the ECtHR which have reinforced the view expressed in the Ibrahim and Others $v$. the UK case concerning a test of fairness of a trial as whole. It is underlined in the conclusions that recent ECtHR's case law does not provide any cause for optimism regarding legal assistance at an early stage of criminal proceedings.

KeYwords: access to a lawyer; criminal proceedings; the European Court of Human Rights; Salduz doctrine.

Resumo: $O$ acesso a um advogado na fase anterior ao julgamento é um componente essencial do direito de defesa no processo penal e do direito a um julgamento justo. $O$ acesso a um advogado permite que o imputado tome uma boa decisão em relação à sua defesa. Atualmente, não há dúvida de que o acesso imediato à defesa técnica constitui um contrapeso importante à vulnerabilidade dos suspeitos sob custódia policial, garante a igualdade de armase fornece uma salvaguarda fundamental contra a coerção. Este estudo analisa o direito do imputado a um advogado na fase inicial da persecução penal na jurisprudência do Tribunal Europeu de Direitos Humanos. A primeira parte do artigo apresenta uma análise da compreensão sobre o direito a um advogado na fase anterior ao julgamento, conforme aplicado pelo TEDH antes do caso Salduz. Esse período foi caracterizado por uma falta de precisão quanto aos limites temporais do direito previsto no artigo $6 .^{\circ}, n .{ }^{\circ} 3$, alínea c, da CEDH. O item subsequente apresenta as mudanças trazidas pelo julgamento do caso Salduz no que diz respeito à proteção dos suspeitos e à garantia de seu direito à defesa técnica. Argumenta-se que a doutrina Salduz não apenas abrangia o acesso do suspeito a um advogado na fase inicial do procedimento prévio ao julgamento, mas também enfatizava a obrigação de informar o suspeito sobre os seus direitos, incluindo o direito de permanecer em silêncio. Um elemento importante da doutrina Salduz era a possibilidade de excluir as provas obtidas durante um interrogatório em investigação preliminar conduzido na ausência de um advogado de defesa. Além disso, argumenta-se que o standard estabelecido no julgamento no caso Salduz v. Turquia foi confirmado em uma série de decisões posteriores. A quarta parte do artigo chama a atenção para a erosão do padrão Salduz que ocorreu com o julgamento no caso Ibrahim 
e outros vs. Reino Unido. O artigo também destaca os recentes acórdãos do TEDH, que reforçaram a opinião expressa no caso Ibrahim e outros c. Reino Unido a respeito de uma verificação de legitimidade do julgamento como um todo. Salienta-se nas conclusões que a jurisprudência recente do TEDH não oferece qualquer motivo para otimismo em relação à assistência jurídica na fase inicial da persecução penal.

Palavras-chave: direito à defesa técnica; processo penal; Tribunal Europeu de Direitos Humanos; doutrina Salduz.

\section{INTRODUCTION}

A suspect's access to a lawyer at an early stage of criminal proceedings and use of a suspect's statements as evidence are controversial issues in literature on the criminal process. Without a doubt, this is also an important practical issue which the judiciary faces on a daily basis. Participation of a defense counsel in the criminal process not only guarantees the right to defense, in particular protection the right against self-incrimination, but also prevents all forms of ill-treatment of the suspect during interrogation, like the use of intimidation or even violence. The right to consult a lawyer also constitutes implementation of the principle of equality of arms from the earliest stage of the proceedings and provides psychological support to the suspect. Information obtained from a suspect at the initial stage of criminal proceedings may be crucial for the final outcome of the detainee's case.

What also must not be overlooked is that the first procedural steps, in particular the presentation of charges and the first interrogation, involve stress on the part of the suspect, which can result in rash decisions that may have a negative impact on the suspect's subsequent outcomes.

Such benefits of assistance of a lawyer as psychological support or protection against any forms of intimidation go beyond the formalistic formula of the right to a lawyer but are inscribed within the concept of procedural justice ${ }^{2}$, which is one of the key principles of a law-abiding

2 Information on procedural justice can be found in: NEUMANN, Ulfrid. Materielle und prozedurale Gerechtigkeit im Strafverfahren. Zeitschrift für die gesamte Strafrechtswissenschaft, v. 101, n. 1, 1989, p. 52-74; SCHWEIGER, 
state. Justice in this sense is when a person against or for whom a trial is being held becomes convinced that the authorities conducting the proceedings have done everything in their power to ensure that the law is complied with by acting in accordance with the law, conscientiously, and in the best interests of that person ${ }^{3}$. Thus, the process must be fair and based on law, but only if the law respects the dignity of an individual, enables an effective exercise of their subjective rights, and seeks to ensure equality of arms, which is an inherent feature of a fair trial. However, this will not happen when the authorities conducting the process take advantage of the defendant's lack of knowledge, mental state, or lack of awareness of their rights. Achievement of such goals as establishing the truth ${ }^{4}$, bringing the guilty person to justice, or freeing an innocent person are not the only values in a criminal process; the way in which substantive justice is achieved is also important. The need for find the balance between substantive justice and formal justice is obvious. While sharing W. Hassemer's view that the search for truth in a criminal process is a tool that protects and enhances human dignity, it should be pointed out that finding the truth when the dignity of a person is violated is unacceptable ${ }^{5}$. The authorities conducting a process should take the utmost care to ensure that the dignity and procedural rights of individuals are respected. Against this background, it becomes clear that statutory safeguards should be established to protect accused persons

F. Theresa. Prozedurales Strafrecht. Baden-Baden: Nomos, 2018, p. 29-188; HÖRNLE, Tatjana; KREMNITZER, Mordechai. Human dignity as a protected interest in criminal law, Israel Law Review, v. 44, n. 1-2, 2011, p. 148-153. SKORUPKA, Jerzy. O sprawiedliwości procesu karnego. Warszawa: WoltersKluwer, 2013, p. 64-87.

3 WALTOŚ, Stanisław; HOFMAŃSKI, Piotr. Proces karny. Zarys systemu, Warszawa 2020, p. 27.

4 WEIGEND, Thomas. Is the Criminal Process about Truth?: A German Perspective. Harvard Journal of Law \& Public Policy, v. 26, n. 1, 2003, p. 157-193.

5 More information can be found in: HASSEMER, Winfried. Human Dignity in the Criminal Process: The Example of the Truth-Finding. Israel Law Review, v. 44, n. 1-2, 2011, p. 187-188; WEIGEND, Thomas; GHANAYIM, Khalid. Human Dignity in Criminal Procedure: A Comparative Overview of Israeli and German Law. Israel Law Review, v. 44, n. 1-2, 2011, p. 198-228; LAGODNY, Otto. Human Dignity and Its Impact on German Substantive Criminal Law and Criminal Procedure. Israel Law Review, v. 33, n. 3, p. 575-591. 
against actions of law enforcement authorities. These can take the form of positive measures, such as informing suspects or accused persons detention of suspects of their rights or of the possibility of exercising their right to remain silent, or creating a statutory procedure for access to a lawyer (defense counsel), as well as negative measures as exclusionary rules concerning statements obtained without access to a lawyer.

The purpose of this paper is to reconstruct and assess the standard of a suspect's access to a lawyer at the initial stage of criminal proceedings in the case law of the European Court of Human Rights (ECtHR). This Court, which enforces the Convention for the Protection of Human Rights and Fundamental Freedoms ${ }^{6}$, is the most important institution of the Council of Europe and plays a significant role in the protection of human rights in Europe. At present, the jurisdiction of the ECtHR has been recognized to date by all 47 member states of the Council of Europe. The ECHR envisages that final judgments of the ECtHR shall be binding only on the parties to the proceedings. As transpires from Article 46(1) of the Convention, Contracting States undertook to abide by the final judgment of the Court in any case to which they are parties. Thus, the judgments of the Court are formally binding only inter partes. However, it can be inferred from Article 1 of the ECHR the Contracting States must take into account the ECtHR's interpretation of the Convention. They therefore have an obligation to "safeguard" Convention rights, as provided in Article 1 of the Convention. It is not surprising, therefore, that Contracting states sometimes draw conclusions also from judgments issued against another state, and therefore give an erga omnes effect to the case-lawof the ECtHR. It also proves that the judgments of the ECtHR enjoy a preventive effect, because other states have amended their laws or practices following judgments of the ECtHR against other states ${ }^{7}$.

6 The European Convention on Human Rights is the oldest international treaty in the field of regional human rights protection. It entered into force on 3 September 1953.

7 POLAKIEWICZ, Jörg: The execution of judgments of the European Court of Human Rights. In: BLACKBURN, Robert; POLAKIEWICZ, Jörg (eds). Fundamental rights in Europe: the European Convention on Human Rights and its member states, 1950-2000, Oxford, Oxford University Press, 2001, p. 73. See also generally ARNARDÓTTIR, Oddný Mjöll. Res Interpretata, Erga Omnes Effect and the Role of the Margin of Appreciation in Giving Domestic Effect 
The aim of this paper is not only to show the Strasbourg system of access to a lawyer, but also to describe its evolution and answer the question of whether de lege lata it ensures effective exercise of the right to defense. This approach is particularly important for the 47 member states of the Council of Europe, as the standard of access to a lawyer at an early stage of criminal proceedings should be similar in their legal systems. This is because any difference in the standards of legal protection of individuals undermines mutual trust between countries with different justice systems and hinders implementation of procedural instruments based on mutual recognition of decisions ${ }^{8}$. Finally, differences in recognizing a suspect's statements made in the absence of a lawyer as admissible evidence can

to the Judgments of the European Court of Human Rights. European Journal of International Law, v. 28, n. 3, 2017, p. 830-834; GERARDS, Janneke: The European Court of Human Rights and the national courts: giving shape to the notion of 'shared responsibility. In: GERARDS, Janneke; FLEUREN, Josepf (eds.), Implementation of the European Convention on Human Rights and of the judgments of the ECtHR in national case law, Cambridge-Antwerp-Portland, Intersentia, 2014, p. 21-34; BODNAR, Adam: 'Res Interpretata: The Legal Effect of the European Court of Human Rights' Judgments for Other States Than Those Which Were Party to the Proceedings. In: HAECK, Yves; BREMS, Eva (eds.). Human Rights and Civil Liberties in the 21st Century, Springer Netherlands, 2014, p. 223.

8 It must be noted that the 27 states-parties of the Convention are EU member states which cooperate according to the principle of mutual recognition of judgments and judicial decisions. Moreover, the European Union's standard regarding access of a suspect to a lawyer at the pre-trial phase of proceedings may not be weaker than that provided in Article 6 of the European Convention on Human Rights and the case law of the European Court of Human Rights that is based on it. As provided in Article $52 \S 3$ of the Charter of Fundamental Rights of the European Union: "In so far as this Charter contains rights which correspond to rights guaranteed by the Convention for the Protection of Human Rights and Fundamental Freedoms, the meaning and scope of those rights shall be the same as those laid down by the said Convention. This provision shall not prevent Union law providing more extensive protection”. About the right of access to a lawyer in European Union law, see e.g. DZIERŻANOWSKA, Joanna. Access to a Lawyer for a Suspect at Early Stage of Criminal Proceedings and Its Participation in Investigative Acts. Review of European and Comparative Law, v. 41, n. 2, 2020, p. 109127; SOO, Anneli. Divergence of European Union and Strasbourg Standards on Defence Rights in Criminal Proceedings? Ibrahim and the others v. the uk (13th of September 2016). European Journal of Crime, Criminal Law and Criminal Justice, v.25, n. 4, 2017, p. 300-303. 
lead to problems in the use of such information in different states or in the recognition of the final judgments. This problem occurs if incriminating statements made during police interrogation without access to a lawyer are used for a conviction.

\section{SUSPECt's ACCESS to LAWYERS IN THE CASE LAW OF THE European Court of Human Rights before the JUdgMENT in the Salduz V. TuRkey CASE}

Access of a criminal suspect to a lawyer is governed by Article 6 $\S 3$ (c) of the ECHR. It provides that "everyone charged with a criminal offense has the following minimum rights (...) to defend himself in person or through legal assistance of his own choosing or, if he has not sufficient means to pay for legal assistance, to be given it free when the interests of justice so require." Originally, the right to a lawyer was strictly interpreted within the temporal limits of Article 6(1) of the Convention, which provides that everyone has the right to a fair and public hearing within a reasonable time by an independent and impartial tribunal established by law. The question arises whether Article 6 of the Convention covers the right of access to a lawyer only at the stage of the court proceedings or whether it also applies at the pre-trial stage. Already in the 1990s, the Court rejected the narrow understanding of Article $6 \S 3$ (c) of the ECHR and in the judgment in the Imbrioscia $v$. Switzerland case assumed that the right of access to a lawyer must be ensured at the pre-trial stage? Since that judgment, there has no longer been any doubt that the right of access to a lawyer must be ensured at the pre-trial stage. However, the way in which the requirements of Article $6 \S 3$ (c) of the ECHR are to be respected in pre-trial proceedings should depend to a large extent on the particular circumstances of the specific trial. The ECtHR's case law emphasizes the need to ensure access to a lawyer during the pre-trial

9 The ECtHR judgement of 24 November 1993 in the case of Imbrioscia $v$. Switzerland, application no. 13972/88, § 36, http://hudoc.echr.coe.int/ eng?i=001-57852; see HARRIS, J. David; O'BOYLE, Michael; WARBRICK, Chris. Law of the European Convention on Human Rights. London, Dublin, Edinburgh: Butterworths, 1995, p. 256. 
phase, usually during interrogations that take place at this stage of the procedure, but also provides for the possibility of limiting this right ${ }^{10}$. One example is the judgment in the John Murray v. the UK case ${ }^{11}$ in which the Court underlined that the right of access to a lawyer, which is not explicitly set out in the Convention, may be subject to restrictions for "good cause". The Court stated that each assessment of such restrictions should be made in the light of the entirety of the proceedings. However, this position of the ECtHR was very general and did not explain anything. First of all, the jurisprudence of the ECtHR does not provide any precise guidance on how to understand the concept of "good cause." Secondly, by assuming that restrictions of the right of access to a lawyer should be assessed from the standpoint of compliance with the requirement of a fair trial as a whole, the ECtHR significantly weakened the essence of this right. Proof of its breach required detailed answers to the questions of whether the rights of defense have been respected and whether an effective defense by a lawyer is possible in the context of the criminal proceedings as a whole. Applying this approach, even in cases of obvious violation of the right of access to a lawyer, the Court ruled out a violation of Article 6 of the ECHR ${ }^{12}$. For example, in Sarikaya v. Turkey, it was

10 However, it should be noted "the right of access to a lawyer arises not only when a person is taken into custody or questioned by the police but may also be relevant during procedural actions, such as identification procedures or reconstruction of the events and on-site inspections", see the ECtHR judgement of 17 February 2009 in the case of Ibrahim Öztürk v. Turkey, application no. 16500/04, §§ 48-49, http://hudoc.echr.coe.int/fre?i=001-91370; the ECtHR judgement of 23 October 2009 in the case of Mehmet Duman v. Turkey, application no. 38740/09, § 41, http://hudoc.echr.coe.int/eng?i=001-187244; the ECtHR judgement of 5 September 2017 in the case of Türk $v$.Turkey, application no. 22744/07, § 47, http://hudoc.echr.coe.int/eng?i=001-176760.

11 See the ECtHR judgement of 9 February 1996 in the John Murray v. the United Kingdom case, application no. 18731/91, § 63, http://hudoc.echr.coe.int/eng? $\mathrm{i}=001-579801$; the ECtHR judgement of 16 October 2001 in Brennan $v$. the United Kingdom, application no. 39846/98, § 45, http://hudoc.echr.coe.int/ eng?i=001-59722.

12 For example, in the case of Mamaç and others $v$. Turkey the Court held that the applicants had not proven that the absence of their lawyer during police custody had affected their rights, see the ECtHR judgement of 20 April 2004 in the case of Mamaç and others $v$. Turkey, application no. 29486/95, 29487/95 and 29853/96, § 43. See also SCHLEGEL, Stephan; WOHLERS, Wolfgang. 
found that no such violation occurred despite the fact that the suspect was denied contact with an attorney for 20 days. In this case the Court held that the applicant enjoyed "overall fairness" by benefitting from legal assistance at the trial.

In contrast, the ECtHR had a different opinion about the violation of the right to access to legal assistance at the pre-trial stage when the national legislation permitted to draw adverse inferences from the suspect's silence at police questioning, and the applicant's right of access to a lawyer had been restricted.

For example, in John Murray $v$. the UK, the ECtHR pointed out that access to a lawyer is of paramount importance for the rights of the defense at the initial stage of police interrogation, where exercising the right to silence may lead to adverse inferences. If the suspect chooses to remain silent, adverse inferences may be drawn against him. Therefore, it is not surprising that the ECtHR's stated that "to deny access to a lawyer for the first 48 hours of police questioning, in a situation where the rights of the defense may well be irretrievably prejudiced, is - whatever the justification for such denial - incompatible with the rights of the accused under Article 6." ${ }^{13}$ A similar conclusion of the Court can be found in the Kolu v. Turkey case ${ }^{14}$. It seems that reasons behind the different approach of the ECtHR to the right of access to a lawyer in a situation

Der »Anwalt der ersten Stunde« in der Schweiz. Strafverteidiger, n. 5, 2012, p. 308-309.

13 The ECtHR judgement of 9 February 1996 in the case of John Murray $v$. the United Kingdom, application no. 18731/91, § 66. About the right to silence before the ECtHR, see SAKOWICZ, Andrzej. Standard of the protection of the right to silence applicable to persons examined as witnesses in the light of the European Court of Human Rights case law. Ius Novum, n. 2, 2018, p. 128-136; OWUSU-BEMPAH, Abenaa, Silence in suspicious circumstances. Criminal Law Review, n. 2, 2014, pp. 126-135.

14 In that judgment, the ECtHR assumed that the lack of access to a lawyer when the applicant made an incriminating statement during an interrogation by police and the circumstances of the case did not indicate that he had been advised of the right to be assisted by a lawyer and the right to remain silent, resulted in an infringement of the right under Article $6 \S 3$ (c) of the ECtHR judgement of 2 August 2005 in the Kolu $v$. Turkey case, application no. 35811/97, http://hudoc.echr.coe.int/eng?i=001-70013; see also the ECtHR judgement of 6 June 2000 in the Magee $v$. the United Kingdom, application no. 28135/95, §§ 44-45, "http://hudoc.echr.coe.int/eng?i=001-58837. 
of violation of the right to silence is due to the high rank of this right. In numerous rulings, the ECtHR has expressed that this right is a "generally recognized international standard which lies at the heart of the notion of a fair procedure under Article 6 of the ECHR." ${ }^{15}$ Unsurprisingly, the ECtHR asserted the right to silence as a rationale for the right to early access to a lawyer, because the latter right is considered to be a safeguard of the enjoyment of others rights.

When summarizing the above observations, it must be said that in the pre-Salduz jurisprudence, the ECtHR recognized the importance of the right of defense during the first interrogation of a suspect by an investigating officer, a member of the public prosecutor's office, or an investigating judge. In many judgments the ECtHR perceived that a lawyer is the one who explains to the suspect their rights, presents the legal situation. Moreover, his presence during the interrogation is a guarantee against ill-treatment of the suspect. However, there have not been any judgments which defined the point in time at which the right to legal assistance arises, or which would precise the scope of admissible restrictions on the right of access to a lawyer (in particular due to the undefined nature of the term "good cause"). The then jurisprudence of the ECtHR also did not define the admissibility of using as evidence statements of a suspect given without access to a lawyer. Consequently, this meant that the assessment of a violation of the fairness of the proceedings in which the right of access to a lawyer was not ensured required account to be taken of the specific circumstances of each case and the legal system ${ }^{16}$. Thus, the failure to provide access to a lawyer at the initial stage of a criminal prosecution did not necessarily automatically mean that the ECtHR found a breach of Article $6 \S 3$ (c) in conjunction with Article

15 GORDON, Van Kessel. European Perspectives on the Accused as a Source of Testimonial Evidence. West Virginia Law Review, vol. 100, 1999, p. 804. See also BERGER, Mark. Self-Incrimination and the European Court of Human Rights: Procedural Issues in the Enforcement of the Right to Silence. European Human Rights Law Review. v. 5, 2007, p. 531.

16 See the ECtHR judgement of 9 February 1996 in the case of John Murray $v$. the United Kingdom, application no. 18731/91, § 63; the ECtHR judgement of 16 October 2001 in the case of Brennan v. the United Kingdom, application no. $39846 / 98, \S .45$; the ECtHR judgement of 6 June 2000 in the case of Magee $v$. the United Kingdom, application no. 28135/95, § 44. 
$6 \S 1$ of the ECHR, since that right, which is not expressly provided for in Article 6 of the ECHR, could be the subject of justified restrictions which, however, in the context of the proceedings as a whole, should not deprive the accused of a fair trial ${ }^{17}$.

\section{The Judgment in the Salduz v. Turkey CASE}

A breakthrough in the case-law of the ECtHR in terms of its approach to the issue of access of a suspect to a lawyer at the initial stage of criminal prosecution was the ruling in the Salduz $v$. Turkey case ${ }^{18}$. The

17 Sometimes it was even claimed that Article $6 \S 3$ (c) does not specify the manner of exercising the right of access to a lawyer or its content, see, the ECtHR judgement (Grand Chamber) of 12 May 2005 in the case of Öcalan v. Turkey, application no. 46221/99, § 135, http://hudoc.echr.coe.int/en$\mathrm{g}$ ? $\mathrm{i}=001-69022$; On the internal structure of Article 6 and the relationship between Article $6 \S 1$ and Article $6 \S 3$ of the Convention. More on this issue see in GOSS Ryan, Out of Many, One? Strasbourg's Ibrahim decision on Article 6, The Modern Law Review, v. 80, no 6, 2017, p. 1137-1163.

18 See, the ECtHR judgement (Grand Chamber) of 27 November 2008 in the case of Salduz v. Turkey, application no. 36391/02, http://hudoc.echr.coe.int/en$\mathrm{g} ? \mathrm{i}=001-89893$. Some scholars say that the Salduz judgement is not clear on this point, see BEIJER, Annemarieke. False confessions during police interrogations and measures to prevent them. European Journal of Crime, Criminal Law \& Criminal Justice, n. 18, 2010, pp. 312-313; OGORODOVA, Anna; SPRONKEN, Taru. Legal Advice in Police Custody: From Europe to a Local Police Station. Erasmus Law Review, v. 4, 2014, p. 191-205. Although the wording of the judgment in the Salduz case may not be very clear, it has resulted in a number of changes in the interrogation rules of several European countries, see GINTER, Jaan; SOO, Anneli. The Right of the Suspect to Counsel in Pre-trial Criminal Proceedings, Its Content, and the Extent of Application. Juridica International, v. XIX, 2012, p. 172; GIANNOULOPOULOS, Dimitrios. Strasbourg Jurisprudence, Law Reform and Comparative Law: A Tale of the Right to Custodial Legal Assistance in Five Countries. Human Rights Law Review, v. 16, n. 1, 2016, p. 103-129; SCHLEGEL, Stephan; WOHLERS, Wolfgang. Der »Anwalt der ersten Stunde « in der Schweiz. Strafverteidiger, v. 5, 2012, p. 309-310. It is even claimed that the Salduz case "represented a milestone in safeguarding the suspect's rights in criminal proceedings at the European level”, see BACHMAIER WINTER, Lorena; THAMAN, C. Stephen. A Comparative View of the Right to Counsel and the Protection of Attorney-Client Communications. In: BACHMAIER WINTER, Lorena; THAMAN, C. Stephen; LYNN, Veronica (eds.). The Right to Counsel and the Protection of Attorney-Client Privilege in Criminal Proceedings. A Comparative View. Springer International Publishing, 2020, 
ruling articulated the principle that any suspect has a right of access to a lawyer from the time of his or her first police interview as follows:

“... in order for the right to a fair trial to remain sufficiently 'practical and effective' ..., Article $6 \S 1$ requires that as a rule, access to a lawyer should be provided as from the first interrogation of a suspect by the police, unless it is demonstrated in the light of the particular circumstances of each case that there are compelling reasons to restrict this right. Even where compelling reasons may exceptionally justify denial of access to a lawyer, such restriction whatever its justification - must not unduly prejudice the rights of the accused under Article 6 (of the ECHR")"19.

In the Salduz judgment it was found that for the first interrogation of a suspect, the Letter of Rights, including the right to remain silent, is insufficient, but it is necessary to provide the individual with access to a lawyer ${ }^{20}$. This is due to the belief that "prompt access to a lawyer constitutes an important counterweight to the vulnerability of suspects in police custody, strengthen equality of arms between the investigating or prosecuting authorities and the suspect" ${ }^{21}$, and contributes to the prevention of miscarriages of justice.

p. 17; JASIŃSKI, Wojciech: Dostęp osoby oskarżonej o popełnienie czynu zagrożonego karą do adwokata na wstępnym etapie ścigania karnego - standard strasburski. Europejski Przegląd Sądowy, n. 1, 2019, p. 25-28; Rights in practice: access to a lawyer and procedural rights in criminal and European arrest warrant proceedings, p. 38-57, Available at: https://fra.europa.eu/en/publication/2019/ rights-practice-access-lawyer-and-procedural-rights-criminal-and-european-arrest. Access on: August 20, 2021.

19 The ECtHR judgement (Grand Chamber) of 27 November 2008 in the case of Salduz v. Turkey, application no. 36391/02, § 55.

20 See the ECtHR judgement of 14 November 2010 in the case of Brusco v. France, application no. 1466/07, § 54, http://hudoc.echr.coe.int/eng?i=001-100969; the ECtHR judgement of 24 November 2013 in the case of Navone and Others v. Monaco, application no. 62880/11, 62892/11 and 62899/11, § 74, http:// hudoc.echr.coe.int/eng?i=001-127928.

21 The ECtHR judgement (Grand Chamber) of 27 November 2008 in the case of Salduz v. Turkey, application no. 36391/02, § 53-55. The scope of the lawyer's actions during the initial stages of proceedings was indicated by the Court in the A.T. v. Luxembourg case (the ECtHR judgement of 9 April 2015, application no. $30460 / 13, \S 64)$, which stated that it includes: discussing the 
In justifying the judgment in Salduz case, the ECtHR stressed that "systematic restriction on the right to be assisted by a lawyer during the pre-trial phase could not constitute a compelling reason", as a basis for limiting the right to lawyer ${ }^{22}$. Such restrictions to having a defense counsel at the pre-trial stage are not compensated for either by the fact that the accused has a defense counsel during court proceedings or by the fact that all the evidence against him or her is presented out in conditions of full adversariality at the trial. As a consequence, the Court found that the right to defense will be irretrievably prejudiced if incriminating statements are used for a conviction and the court believes the explanations made during the investigation. This was clearly emphasized by the Court when it stated that: "neither the assistance provided subsequently by a lawyer nor the adversarial nature of the ensuing proceedings could cure the defects which had occurred during police custody." ${ }^{23}$ In this regard, Giannoulopoulos rightly points out that the use of confessional evidence obtained during custodial interrogation without access to a lawyer irretrievably prejudices the right to a fair trial and amounts to automatic violation of the Article $6 \S 3$ (c) of the $\mathrm{ECHR}^{24}$, unless there were compelling reason for the

case; organizing the defense; collecting evidence favorable to the accused; preparing the accused for questioning; supporting the accused in distress; checking the conditions of detention; and helping to ensure respect for the right of the accused not to incriminate himself; see more JACKSON, D. John, Responses to Salduz: procedural tradition, change and the need for effective defence. Modern Law Review, n. 6, v. 76, 2016, p. 995-996.

In most of these cases, the majority against Turkey but some against other States such as Monaco, Luxembourg, Malta, Belgium and France, the Court has not analyzed the overall fairness of the proceedings, but has found an automatic violation on the basis of a systematic statutory restriction; see the ECtHR judgement of 13 October 2009 in the case of Dayanan $v$. Turkey, application no. 7377/03, § 33; http://hudoc.echr.coe.int/eng?i=001-95015; the ECtHR judgement of 9 February 2010 in the case Boz $v$. Turkey, application no. 2039/04, § 35 http://hudoc.echr.coe.int/eng?i=001-97199; the ECtHR judgement of 27 October 2011 in the case Stojković v. France and Belgium, application no. 25303/08, § 51-57, http://hudoc.echr.coe.int/eng?i=001-107177; the ECtHR judgement of 12 January 2016 in the case of Borg $v$. Malta, application no. 37537/13, § 59-63, http://hudoc.echr.coe.int/eng?i=001-159924.

23 The ECtHR judgement (Grand Chamber) of 27 November 2008 in the case of Salduz $v$. Turkey, application no. 36391/02, § 55.

24 GIANNOULOPOULOS, Dimitrios. Improperly Obtained Evidence in Anglo-American and Continental Law. Oxford: Hart Publishing, 2019, p. 172. 
interview. However, the restrictions applied, even if justified, could not undermine the right to a fair trial, and they must be exceptional ${ }^{25}$.

The „Salduz” doctrine applies in case of vulnerable suspects. Vulnerability may be caused by various circumstances. In the Salduz case, it was the young age of the suspect. The ECtHR noted that, in the case of suspects who are children as defined by international standards (i.e. persons under the age of 18 at the time of an interrogation as suspects), it is not enough merely to inform them about their right to remain silent and their right to have a lawyer. It stated that juvenile suspects and other persons who can be classified as vulnerable suspects (e.g. the elderly, persons with mental disabilities, or persons with a pre-existing heart condition) are not able to assess their legal situation and knowingly exercise their right to remain silent, even if they have been properly advised about $\mathrm{it}^{26}$.

In short, it seems that the ECtHR decided to depart from its previous holistic approach. This is of particular importance in view of the ECtHR's statement that the rights of the defense will in principle be

25 See the ECtHR judgement (Grand Chamber) of 27 November 2008 in the case of Salduz v. Turkey, application no. 36391/02, § 54; the ECtHR judgement of 28 October 2010 in the case Leonid Lazarenko v. Ukraina, application no. 22313/04, § 50, http://hudoc.echr.coe.int/eng?i=001-101321; CZERNIKA, Dominika. Prawo podejrzanego do kontaktu z adwokatem (art. 6 ust. 3 lit. c EKPCz) w orzecznictwie Europejskiego Trybunału Praw Człowieka Europeski Przegląd Sądowy, nr 9, 2017, p. 28-39.

There is a trend in recent case-law to refer to this standard for all suspects, in particular: the ECtHR judgement of 28 October 2010 in the case of Leonid Lazarenko v. Ukraina, application no. 22313/04, § 53-59, http://hudoc.echr. coe.int/eng?i=001-101321; the ECtHR judgement of 17 December 2013 in the case Potcovăv. Rumunia, application no. 27945/07, § 25-32, http://hudoc. echr.coe.int/eng?i=001-139272. PERONI,Lourdes; TIMMER, Alexandra. Vulnerable Groups. the Promise of an Emergent Concept in European $\mathrm{Hu}-$ man Rights Convention Law. International Journal of Constitutional Law, n. 11, 2013, p. 1056-1085; TIMMER, Alexandra. A Quiet Revolution: Vulnerability in the European Court of Human Rights. En: FINEMAN, Albertson; GREAR, Anna (eds.). Vulnerability: Reflections on a New Ethical Foundation for Law and Politics, Farnham: Ashgate, 2013, p. 147-170; WĄSEK-WIADERER, Małgorzata: Model zakazów dowodowych z perspektywy Konwencji i orzecznictwa ETPCz. En: SKORUPKA, Jerzy; DROZD, Anna (eds.). Nowe spojrzenie na model zakazów dowodowych w procesie karnym, Warszawa: C. H. Beck, 2015, p. 38-39. 
irretrievably prejudiced when incriminating statements made during police interrogation without access to a lawyer are used as evidence and constitute a basis for conviction. It seems that the Court simply considered the first questioning of a suspect by the police to be a crucial moment of great importance for the criminal proceedings as a whole. From this viewpoint, in the case of vulnerable suspects, the use of incriminating explanations given by suspects in the absence of their defense counsels or in situations where suspects are unable to consult their defense counsels before starting the interrogations as evidence has become inadmissible. In such a situation, denial of access to a lawyer cannot be seen as a harmless error, which can be corrected.

However, notwithstanding the fact that the judgment in the Salduz $v$. Turkey case was limited in terms of the object, it can be assumed that it reaffirmed the suspect's right to legal assistance of a lawyer as one of the fundamental characteristics of a fair trial. It also clarified the standard of access to a lawyer for a suspect in police custody. At the same time, it must be added that assigning a counsel does not in itself ensure the effectiveness of the assistance he or she may afford an accused. In order to exercise their right to defense, a suspect must be possible to consult with his or her lawyer prior to an interview and the lawyer must be physically present during their initial police interviews ${ }^{27}$.

27 See, the ECtHR judgement of 14 November 2010 in the case of Brusco $v$. France, application no. 1466/07, § 151-153; the ECtHR judgement of 9 April 2015 in the case of A.T. v. Luxembourg, application no. 30460/13, § 86-88; the ECtHR judgement of 21 June 2011 in the case of Mađer $v$. Croatia, application no. 56185/07, § 151-153, http://hudoc.echr.coe.int/en$\mathrm{g} ? \mathrm{i}=001-105293$; the ECtHR judgement of 28 June 2011 in the case of Šebalj v. Croatia, application no. 4429/09, § 256-257, http://hudoc.echr.coe.int/ eng?i=001-105413; the ECtHR judgement of 25 April 2013 in the case of Erkapić v. Croatia, application no. 51198/08, § 80, http://hudoc.echr.coe. int/eng?i=001-118734. It is obvious that such physical presence must enable the lawyer to provide assistance that is effective and practical rather than merely abstract; see: the ECtHR judgement of 9 April 2015 in the case of A.T. v. Luxembourg, § 87. Moreover, having access to a lawyer ensures that the accused was able to make a good decision for his or her defence, see the ECtHR judgement of 28 October 2010 in the case of Leonid Lazarenko $v$. Ukraine, application no. 22313/04, § 50, http://hudoc.echr.coe.int/ eng? $\mathrm{i}=001-101321$. 


\section{Post-Salduz case-law}

The standard set out in the judgment in the Salduz v. Turkey case was confirmed in the Tikhonov $v$. Ukraine case ${ }^{28}$. The judgment recognized that suspects are not able to assess their legal position at an early stage of the proceedings and to consciously exercise their right to remain silent, even if they have been properly informed about it. Of a significant influence on this position was the fact that in this case, during detention and before the first interrogation, the suspect was informally questioned by law enforcement officers ${ }^{29}$. The Court perceived that this form of detention effectively deprived the suspect of prompt judicial review of his detention and exposed him to a risk of unlawful pressure and coercion. Consequently, it could not be assumed that the suspect waived his right to a lawyer in circumstances which were attended by minimum safeguards commensurate to the importance of such a waiver ${ }^{30}$.A similar opinion was expressed in the Panovits $v$. Ciprus ${ }^{31}$ case where it was found that the applicant's right to a fair trial was violated as a result of failure to allow him to exercise his right to defense in the pre-trial proceedings (Article $6 \S 3$ (c) in conjunction with Article $6 \S 1$ of the ECHR) and because of the use as evidence of explanations of the accused obtained in violation of the standards of fair trial (Article $6 \S 1$ of the ECHR). The key fact of the case was that the 17-year-old suspect was not offered the assistance of a defense counsel before the interrogation and the suggestion that a defense counsel should be sought was given only to the applicant's father when the suspected minor was already being interrogated. In view of

28 See, the ECtHR judgement of 10 December 2015 in the case of Tikhonov v. Ukraine, application no. 17969/09, § 50-52, http://hudoc.echr.coe.int/ eng?i=001-159054.

29 See, WĄSEK-WIADERER, Małgorzata: Model zakazów dowodowych z perspektywy Konwencji i orzecznictwa ETPCz. En: SKORUPKA, Jerzy; DROZD, Anna (eds.). Nowe spojrzenie na model zakazów dowodowych w procesie karnym, Warszawa: C. H. Beck, 2015, p. 38-39; CZERNIKA, Dominika. Prawo podejrzanego do kontaktu $\mathrm{z}$ adwokatem, op.cit, p. 32.

30 See, the ECtHR judgement of 10 December 2015 in the case of Tikhonov $v$. Ukraine, application no. 17969/09, § 51.

31 The ECtHR judgement of 11 November 2008 in the case of Panovits v. Cyprus, application no. 4268/04, § 67, http://hudoc.echr.coe.int/eng?i=001-90244. 
these circumstances the Court noted that "the right of an accused minor to effective participation in his or her criminal trial requires that he be dealt with due regard to his vulnerability and capacities from the first stages of his involvement in a criminal investigation and, in particular, during any questioning by the police.." ${ }^{32}$. Thus, under the case law of the ECtHR, the right to counsel as from the initial stages of criminal justice is considered a fundamental value of the right to a fair trial, with particular relevance for the position of minors subjected to police interrogations, as individuals in need of additional protection Such a position of the ECtHR was based on the assumption that the applicant and his father did not expressly and unequivocal waive appellant's right to lawyer prior to his interrogation ${ }^{33}$.

In the Panovits $v$. Cyprus case, the applicant also raised the claim of use in court proceedings of the applicant's explanations given in the pre-trial proceedings. With reference to the claim, the Court pointed out that the applicant's admission of guilt obtained in circumstances that infringed the standards of Article 6 of the Convention was the decisive proof on which the charges in the case were based. This significantly reduced the applicant's chances of being able to defend himself effectively at the stage of the court proceedings and, consequently, irreparably undermined his rights of defense $\mathrm{e}^{34}$. This could only be avoided in one way,

32 The ECtHR judgement of 11 November 2008 in the case of Panovits v. Cyprus application no. 4268/04, § 67.

33 This conclusion was criticized by Judge ad hoc Erotocritou, who in his dissenting opinion drew a distinction between the denial of a right to access legal assistance and a failure to inform the individual of the existence of such a right. The ECtHR Judge Erotocritou observed that the applicant, less than 24 hours after his arrest, had the services of a lawyer, who represented him at the remand proceedings the very next day. Within one week he appointed he appointed a second lawyer and, throughout the one and a half years the trial lasted, he was at all legally represented and had the opportunity to test all the evidence, see dissenting opinion of the ECtHR Judge ad hoc Erotocritou, the judgement of 11 November 2008 in the case of Panovits v. Cyprus, application no. 4268/04. See also OGORODOVA, Anna; SPRONKEN, Taru. Legal Advice in Police Custody: From Europe to a Local Police Station, op.cit., p. 195-199.

34 Most notably, the ECtHR judgement of 11 November 2008 in the case of Panovits v. Cyprus, application no. 4268/04..., § 75, 84-86; See SCHABAS, A. William. The European Convention on Human Rights. A Commentary. Oxford: Oxford University Press: 2015, p. 301 and 310. 
namely by not allowing the use of self-incriminating statements made by the suspect in the pre-trial proceedings before he had the opportunity to consult his lawyer.

The line of judgments known as the "Salduz doctrine" 35 also includes the judgment issued in the Ptonka v. Poland case ${ }^{36}$ in which the ECtHR found a violation of Article $6 \S 1$ in conjunction with Article 6 $\S 3$ of the ECHR. In this case, the applicant signed the report from the interrogation, while being informed about her right to a lawyer and her right to refuse to testify. The applicant was arrested on a charge of murder. The day after her detention, she was presented with the charges and familiarized with the list of procedural rights and obligations, which she confirmed with her handwritten signature. On that day the suspect was interrogated by a prosecutor. In her explanation one day and two days after the arrest, she stated that the victim (the deceased) was a friend of hers from work with whom she used to consume alcohol. She also raised the fact that she had been an alcoholic for 20 years and that she did not remember the whole event exactly, but only that there was an argument between her and the victim while they were drinking alcohol together and that she hit him a few times with scissors. In deciding the case, the ECtHR found that the suspect had not made a clear and unequivocal waiver of her right to a defense counsel, particularly during the interrogation when the applicant pleaded guilty in the absence of her lawyer. Although the applicant withdrew her previous statements in the course of the court proceedings, it was the explanations submitted to the police officers that influenced her conviction and the final judgment.

35 See JACKSON, D. John. Common Law Evidence and the Common Law of Human Rights: Towards a Harmonic Convergence? Towards a Harmonic Convergence?. William \& Mary Bill of Rights Journal, v. 27, n. 3, 2019, p. 690 and 710. VAN DE LAAR, Tom; DE GRAAFF, Regien. Salduz and Miranda: Is the US Supreme Court Pointing the Way?. European Human Rights Law Review, v. 3, 2011, p. 304-317. About the psychological and humanitarian aspect of the right to a defence in an interesting way writes S. Trechsel, see, TRECHSEL, Stefan. Human Rights in Criminal Proceedings. Oxford New York: Oxford University Press: 2005, p. 245-247.

36 The ECtHR judgement of 31 March 2009 in the case Płonka v. Poland, application no. 20310/02, § 42, http://hudoc.echr.coe.int/eng?i=001-91927. 
The Court pointed out that the effectiveness of a waiver of rights under the ECHR depends on whether it takes place in an express and irrevocable manner and is accompanied by the provision of minimum guarantees appropriate to the gravity of the waiver ${ }^{37}$. According to the Court, in the circumstances of the case, the notification, provided in the rights and obligations form, of the right to remain silent and to have a lawyer cannot be regarded as reliable, since the suspect suffered from an alcoholic disease and, together with the deceased, drank a significant amount of alcohol one day before her detention. There should be no doubt that the suspect was a vulnerable suspect and, therefore, the authorities conducting the process should have taken this fact into account during the interrogation, in particular with regard to the assessment of her right to have a lawyer during that part of the procedure ${ }^{38}$. Having regard to those circumstances, the Court found that the absence of a defense lawyer at the first hearing undoubtedly had a negative impact on her procedural situation. Consequently, neither the subsequent representation of the applicant by a defense counsel nor the adversarial process of the court proceedings were capable of offsetting the negative consequences of the absence of a lawyer at the first interrogation.

In summary, several conclusions can be drawn from the statements of the ECtHR based on the judgment in the Salduz $v$. Turkey case. First of all, the court clearly emphasized the importance of legal assistance during the pre-trial phase. One might even say, that this constitutes formulation of the principle that as a rule, access to a lawyer should be provided as from the first interrogation of a suspect. However, the Court did not accept it in an absolute form, by pointing out that if, in the light of the specific

37 The ECtHR judgement of 31 March 2009 in the case Ptonka v. Poland, application no. 20310/02, § 37, http://hudoc.echr.coe.int/eng?i=001-91927. See the ECtHR judgement (Grand Chamber) of 25 October 2015 in the case of Dvorski v. Croatia, application no. 25703/11, § 100, http://hudoc.echr.coe. int/eng?i=001-158266

38 The ECtHR judgement of 31 March 2009 in the case Płonka v. Poland, application no. 20310/02, § 38, http://hudoc.echr.coe.int/eng?i=001-91927; see also the ECtHR judgement of 5 September 2017 in the case of Türk v. Turkey, application no. 22744/07, § 53-54, http://hudoc.echr.coe.int/ eng?i=001-176760; 
circumstances of the case there are compelling reasons for restricting that right, that is permissible, although it must be exceptional ${ }^{39}$.

Secondly, it is not permissible to use self-incriminating statements made by the suspect during the pre-trial proceedings before he or she had the opportunity to consult his lawyer. The ECtHR rightly underlined that a suspect's position at the early stage of criminal proceedings is particularly vulnerable also due to the complexity of rules governing gathering and use of evidence in criminal case ${ }^{40}$.

Thirdly, for vulnerable suspects, advising them of their rights is not sufficient. If these persons are unable to assess their situation properly and understand the procedural consequences of waiving their right of access to a lawyer and their right to remain silent, it is the duty of the authorities conducting the proceedings to ensure that they are able to get the assistance of a lawyer before the first interrogation. Fourthly, if the suspect is conscious and there are no other circumstances suggesting that he or she should be considered as a vulnerable suspect, he or she may effectively waive the right of access to a lawyer and the right to remain silent, if he or she has been informed of this before the first interrogation ${ }^{41}$. He or she must make a free and informed decision to waive his or her rights. The mere fact of proceeding to provide explanations cannot be regarded as an effective and fully informed waiver of the right to have a defense counsel if the suspect has previously, prior to the interrogation,

39 the ECtHR judgement of 21 December 2010 in the case of Hovanesian $v$. Bulgaria, application no. 31814/03, § 34, http://hudoc.echr.coe.int/en$\mathrm{g}$ ? $\mathrm{i}=001-102391$; the ECtHR judgement of 9 April 2015 in the case A.T. $v$. Luxembourg, application no. 30460/13..., § 64; the ECtHR judgement of 20 October 2015 in the case 25703/11, § 78, http://hudoc.echr.coe.int/en$\mathrm{g} ? \mathrm{i}=001-158266$. GRABENWARTER, Christoph. European Convention on Human Rights. Commentary. München: C. H. Beck; Oxford: Hard; BadenBaden: Nomos; Basel: Helbing Lichtenhahn Verlag, 2014, p. 159.

40 The ECtHR judgement (Grand Chamber) of 27 November 2008 in the case of Salduz v. Turkey, , application no. 36391/02, § 54.

41 A suspect cannot be found to have waived one's right to legal assistance if one has not promptly received information about this right after arrest, see the ECtHR judgement (Grand Chamber) of 12 May 2017 in the case of Simeonovi v. Bulgaria, application no. 21980/04, § 118, http://hudoc.echr.coe.int/ eng?i=001-172963. 
requested to be given access to his or her defense counsel, which has been ignored by the law enforcement authorities ${ }^{42}$.

The use of the Salduz doctrine in ECtHR's case-law confirm that the right of access to a lawyer does not arise solely in connection with possible interrogation of a suspect by the police and the risk of such a person giving incriminating statements. It applies during the entire interrogation phase and not simply prior to, or during, the questioning of the suspect ${ }^{43}$. As indicated in the Dayanan case ${ }^{44}$, the fairness of proceedings requires that lawyer be to accomplish the fundamental aspects of defense: discussion of the case, organization of the defense, collection of evidence favorable to the accused, preparation for questioning, support of an accused in distress and checking of the conditions of detention ${ }^{45}$.

The applicant in this case remained silent throughout the entire period of police detention as well as during the trial. He was found guilty of belonging to a terrorist group based on other evidence. However, the Court found a breach of Article $6 \S 1$ of the ECHR in conjunction with Article $6 \S 3$ (c) in that the accused had no access to a lawyer during the time spent in police custody. The judgment in the Dayanan case was a decisive step towards an autonomous understanding of the right to legal assistance and the right to defense in the case law of the ECtHR. Whilst recognizing the importance of this right, the Court was right to conclude

42 See, the ECtHR judgement of 24 September 2009 in the case of Pishchalnikov v. Russia, application no. 7025/04, § 76-92, http://hudoc.echr.coe.int/ eng?i=001-94293; about the defendant's free will during pre-trial detention, see SUXBERGER, Antonio H. G.; MELLO, Gabriela S. J. V. A voluntariedade da colaboração premiada e sua relação com a prisão processual do colaborador. Revista Brasileira de Direito Processual Penal, Porto Alegre, vol. 3, n. 1, p. 189-224, 2017, https://doi.org/10.22197/rbdpp.v3i1.40.

43 On the scope of the concept of the right to legal advice, see LEVERICK, Leverick, Fiona. The Right to Legal Assistance During Detention. Edinburgh Law Review, v. 15, 2011, p. 354; GIANNOULOPOULOS, Dimitrios. Strasbourg Jurisprudence, Law Reform and Comparative Law: A Tale of the Right to Custodial Legal Assistance in Five Countries. Human Rights Law Review, v. 16, n. 1, 2016, p. 106.

44 The ECtHR judgement of 13 October 2009 in the case of Dayanan v. Turkey, application no. 7377/03, § 32, http://hudoc.echr.coe.int/eng?i=001-95015.

45 GRABENWARTER, Christoph. European Convention on Human Rights. Commentary, op.cit., p. 158. 
that a breach of Article $6 \S 3$ (c) does not require proof that the absence of a lawyer during the initial police custody harmed the interests of the accused, e.g. by resulting in him giving testimony that incriminated him. In other words, the Court ruled that, generally speaking, restrictions on the right of access to a lawyer automatically constituted a breach of the accused's right to a fair trial

Finally, in Pishchalnikov $v$ Russia, the ECtHR removed any doubts concerning the need for about the lawyer's presence at questioning, by holding that "who had expressed his desire to participate in investigative steps only through counsel, should not be subject to further interrogation by the authorities until counsel has been made available to him" ${ }^{46}$. Such firm statements by the ECtHR allow us to assume that the Salduz doctrine also included the rule prohibiting the use of statements obtained during police interrogation in the absence of lawyers at trial, unless the suspect, fully aware of the significance and consequences of his decision, waives the opportunity to consult a counsel and the right to remain silent. The existence of such a prohibition was intended to prevent situations where the right to defense is irretrievably prejudiced. There is no doubt that such prejudice determines the overall fairness of a trial per se and is irreparable. It cannot be remedied without the exclusionary rule.

\section{Erosion of the Salduz doctrine}

The Salduz doctrine dominated the ECtHR's case-law for 8 years until the landmark judgment in the Ibrahim and Others case $\mathrm{e}^{47}$. Before any conclusions can be drawn from this case, the facts of the case

46 See, the ECtHR judgement of 24 September 2009 in the case of Pishchalnikov v. Russia, application no. 7025/04, § 79, http://hudoc.echr.coe.int/ eng?i=001-94293.

47 The ECtHR judgement (Grand Chamber) of 11 September 2016 in the case of Ibrahim and Others $v$. the United Kingdom, application no. 50541/08, 50571/08, 50573/08 and 40351/09, http://hudoc.echr.coe.int/eng?i=001-166680. On the retreat from the Salduz doctrine, see more, CELIKSOY, Ergul. Ibrahim and Others v. UK: Watering down the Salduz principles? New Journal of European Criminal Law, v. 9, n. 2, 2019, p. 229-246; JASIŃSKI, Wojciech: Dostęp osoby oskarżonej o popełnienie czynu zagrożonego karą do adwokata na wstępnym etapie ścigania karnego - standard strasburski..., p. 28-29. 
should be described in a few words. This case involved four bombers who planted explosives on the London transport system. The first three suspects were arrested and questioned by the police in urgent "safety interviews". The interviews were held prior to providing the suspects access to legal advice. Under the Terrorism Act of 2000, interrogation could take place in the absence of a lawyer even before the detainee was given the opportunity to request legal assistance. During the interrogations, the suspects in question denied their involvement in the attacks and their explanations given during the "safety interviews" were counted as evidence for the purpose of the criminal trial. The Court had no doubt that at the time of their initial questioning by the police there was "an urgent need to avert serious adverse consequences for the life and physical integrity of the public". This allowed the Court to conclude that there were compelling reasons for the temporary restrictions on their right to legal advice. The legal situation of the fourth applicant was different. He was not suspected of detonating a bomb and was initially questioned by police as a witness. During his testimony, however, he began to incriminate himself by confirming his relationship with one of the suspects immediately after the attacks and providing information about the help he gave him. Nevertheless, he was not formally detained or informed of his right to remain silent and his right to legal aid at that time. It was only after the interrogation was completed that he was formally detained and given legal assistance. Under the circumstances, the ECtHR concluded that the overall fairness of fourth applicant's trial had been prejudiced by restricting his access to legal advice ${ }^{48}$.

An analysis of the justification in the Ibrahim and Others case allows to draw the conclusion that for the ECtHR the right to early access to a lawyer is not aim in itself. In this case again the holistic approach was applied providing that each violation of this right must be examined with regard to the development of the proceedings as a whole and "not on the basis of an isolated consideration of one

48 The ECtHR judgement (Grand Chamber) of 11 September 2016 in the case of Ibrahim and Others $v$. the United Kingdom, application no. 50541/08, 50571/08, 50573/08 and 40351/09, § 311. 
particular aspect or one particular incident" ${ }^{49}$. Further on, the Court unequivocally stated that "where a respondent government have convincingly demonstrated the existence of an urgent need to avert serious adverse consequences for life, liberty or physical integrity in a given case, this can amount to a compelling reason to restrict access to legal advice for the purposes of Article 6 of the ECHR." ${ }^{50}$ In allowing an exception to the right of access to counsel, the Court added that the criterion of compelling reasons should be based on domestic law and interpreted narrowly ${ }^{51}$.

The ECtHR stressed, however, that even the absence of compelling reasons does not automatically lead to a violation of rights under Article 6. Also in this situation, it is necessary to conduct to overall fairness test in order to decide on the violation of Article 6 rights. An important consequence of the judgment in the Ibrahim and Others case was that the ECtHR clarified the test on whether a restriction on access to a lawyer is compatible with the right to a fair trial. The test set out in Salduz was composed of two stages. In the first stage the Court must assess whether or not there were compelling reasons to justify the restriction on the right of access to a lawyer. In the second stage, it must examine the impact of the restriction on the overall fairness of the proceedings. Unfortunately, in the Ibrahim and Others case the Court confirmed the need for both the two-stage test and accepted the possibility that evidence obtained from a suspect in violation of his right of access could be used to his prejudice at his trial. Moreover, in this case a non-exhaustive list of factors to be taken into account when assessing the proceedings as a whole was adopted defined, i.e.: the age or mental capacity, the legal framework governing the pre-trial proceedings and the admissibility of evidence at trial, the opportunity to challenge the authenticity of the evidence and oppose its use, the use to which the evidence was put, and in particular whether the evidence formed significant part of the probative evidence upon which the conviction was based, whether the assessment of guilt was

\footnotetext{
49 Ibid., § 251.

50 Ibid., § 259.

51 Ibid., $§ 258$.
} 
performed by professional judges, and the weight of the public interest in the investigation ${ }^{52}$.

The adoption of the above "non-exhaustive list" of factors to be taken into account in order to assess the impact of procedural failings at the pre-trial stage resulted in a departure from the standard of access to a lawyer at the pre-trial stage as proposed in the Salduz case. The list of circumstances, presented by the ECtHR, is arbitrary. Consequently, the predictability of the Strasbourg Court's decisions is limited. Depending on the failing that is found to be decisive, it may turn out that obtaining incriminating evidence in the absence of a lawyer and its use in the trial is not decisive for verification of procedural fairness. Moreover, the very selection of the failings that occurred at the pre-trial stage is unclear. It is unreasonable to place in the same category the infringement of the rights of a vulnerable suspect, with the possibility of using incriminating statements obtained from an interrogated person who has been deprived of any contact with a lawyer, and a situation where the assessment of an accused person's guilt was made by a professional judge or a jury and the weight of the public interest in the investigation and punishment of the particular offense in issue. Nor can it be concluded that adjudication of a case by a jury or the possibility of challenging in a trial the incriminating statements obtained from a suspect when his or her right to be assisted by a lawyer had been restricted is in any way likely to "heal" the criminal process as a whole when one of the main determinants of fairness of the criminal proceedings, i.e. the right to a lawyer, has been violated in the pre-trial proceedings. This is true regardless of how we view the rules of analysis of failings that occur at the pre-trial stage that were adopted in the Ibrahim and Others case and in what configuration they occur. This is because, the right to defense is always irreversibly compromised when incriminating testimony given without access to a defense counsel is used in criminal proceedings. Finally, it should be added that the negative effect of the ECtHR's approach is that, in principle, there is no clear countryspecific guidance on how to create national rules for ensuring effective

52 The ECtHR judgement (Grand Chamber) of 11 September 2016 in the case of Ibrahim and Others $v$. the United Kingdom, application no. 50541/08, 50571/08, 50573/08 and 40351/09, , § 274 . 
access of suspects to lawyers. The ECtHR's imprecise way of assessing the fairness of the proceedings requires a case-by-case approach and makes it difficult to decide in general way that could serve as a binding guide on how the various factors affect the assessment of compliance with the procedural fairness requirement. ${ }^{53}$

The judgment in the Ibrahim and Others case, due to the large number and the variety of the criteria for assessing the fairness of the proceedings as a whole, opened the possibility to reduce the guaranteed protection as regards access to a lawyer. Also not without significance was the ECtHR's conclusion that even where there has been an unjustified restriction of the right of access to a lawyer and the suspect has made incriminating statements and these have been used against him or her, a breach of Article $6 \S 3$ (c) of the ECHR does not have to have taken place. After Ibrahim and Others case, the erosion of the Salduz doctrine quickly began, with the consequent weakening of the suspect's rights at the initial stage of criminal proceedings. This is evidenced by the judgments issued following the judgment in the Ibrahim and Others case in which the Court found no infringement of Article $6 \S 3$ (c) of the ECHR, even though the applicant was unjustifiably denied access to a lawyer and made incriminating statements that were used against him ${ }^{54}$. On the basis of

53 The only advantage that results from the judgment in the Ibrahim and Others case appears to be the fact that the ECtHR expressly confirmed that the right to be assisted by a lawyer applies from the moment a person is accused of an offense in the autonomous sense of the term given to it by the ECtHR case law. Therefore, the right does not apply from the time of the first interrogation, when the person is formally presented with charges, but from the time of the first action of the authorities conducting the process that is aimed to prosecute the person. See also the discussion on the Ibrahim and Others case, GOSS Ryan, Out of Many, One? Strasbourg's Ibrahim decision on Article 6, The Modern Law Review, v. 80, no 6, 2017, p. 1137-1163; CELIKSOY, Ergul. Ibrahim and Others v. UK: Watering down the Salduz principles? New Journal of European Criminal Law, v. 9, n. 2, 2019, p. 229-246; GIANNOULOPOULOS, Dimitrios. Improperly Obtained Evidence in Anglo-American and Continental Law. Oxford: Hart Publishing, 2019, p. 165-199.

In this case, the ECtHR has done away with the automatic exclusion of statements received in a context of the unlawful restriction of the right of access to a lawyer, see SOO, Anneli. Divergence of European Union and Strasbourg Standards on Defence Rights in Criminal Proceedings? Ibrahim and the others v. the uk (13th of September 2016). European Journal of Crime, Criminal 
recent judgments of the Court ${ }^{55}$, it must be assumed that the aim is no longer to ensure that every suspect has access to a lawyer before the first questioning and, in the event of a failure to fulfill that obligation, to declare a breach of Article $6 \S 3$ (c) of the ECHR. The exclusion of incriminating statements obtained during such a questioning as evidence in the trial is also less important. What becomes more and more important is the right to be informed about the content of the charges and the right to remain silent, and not to be forced to make statements in the absence of a lawyer if the suspect has refused to make them or has stated that he or she would not make any statements until he or she has consulted a lawyer. The ECtHR stresses that in principle there can be no justification for a failure to notify a suspect of these rights.

Such a conclusion can be reached by reading of the judgment in the Simeonovi v. Bulgaria case ${ }^{56}$, which argues that the lack of information about rights, the fact that advantage was taken of a person's insufficient awareness of his rights, and the violation of the right not to incriminate oneself violates the fairness of the proceedings more than a temporary restriction of contact with a lawyer.

The Court's position expressed in the Ibrahim and Others case is also followed in the Beuze v. Belgium case ${ }^{57}$. In the Beuze case, a two-step test was introduced, in accordance with which the Court ought first of all to consider whether there are compelling reasons that justify restricting

Law and Criminal Justice, v.25, n. 4, 2017, p. 335. See also the ECtHR judgement of 16 February 2017 in the case of Artur Parkhomenko v. Ukraine, application no. 40464/05, § 83-91, http://hudoc.echr.coe.int/eng?i=001-171473.

55 See, the ECtHR judgement (Grand Chamber) of November 2018 in the case of Beuze v. Belgium, application no. 71409/10, http://hudoc.echr.coe. int/eng?i=001-187802; the ECtHR judgment of 27 April 2017 in the case of Zherdev v. Ukraine, application no. 34015/07; he ECtHR judgement (Grand Chamber) of 12 May 2017 in the case of Simeonovi v. Bulgaria, application no. 21980/04, § 118, http://hudoc.echr.coe.int/eng?i=001-172963.

56 The ECtHR judgement (Grand Chamber) of 12 May 2017 in the case of Simeonovi v. Bulgaria, application no. 21980/04, \& 138-143.

57 The ECtHR judgement (Grand Chamber) of November 2018 in the case of Beuze v. Belgium, no. 71409/10.. See more CELIKSOY, Ergul. Overruling 'the Salduz Doctrine' in Beuze v Belgium: The ECtHR's further retreat from the Salduz principles on the right to access to lawyer. New Journal of European Criminal Law, v. 10, n. 4, 2019, p. 342-362. 
an applicant's access to a lawyer. In the absence of such compelling reasons, the Court should merely apply a "strict scrutiny" to the second stage of the test, which requires an assessment of the overall fairness of the proceedings, using the criteria from the Ibrahim and Others case $\mathrm{e}^{58}$. In this judgment, the ECtHR departed from its earlier assumption that a restriction on access to a lawyer of a systemic nature (i.e. where national legislation prohibits contact with a defense counsel) results in automatic violation of Article $6 \S 1$ and $\S 3$ (c) of the ECHR.

The above position was quite soon confirmed in the Zherdev $v$. Ukraine $^{59}$ and Doyle v. Ireland case ${ }^{60}$. In the first judgement, the ECtHR pointed out that the courts deciding the case did not rely on an admission made in the absence of alawyer. The defendant was also allowed to challenge the authenticity of the incriminating evidence at the trial, he did not withdraw his guilty plea, and there was other decisive evidence that determined the conviction. Given that the case involved murder, the ECtHR had no doubt that there was a public interest in holding the perpetrator criminally liable. Consequently, the ECtHR assumed, despite the applicant's age, that there had been no violation of Article $6 \S 1$ and $\S 3$ (c) of the ECHR. The significance of inculpatory evidence other than the confession and the defendant's procedural position in the main proceedings weighed on this decision.

A similar conclusion was reached by the ECHR, in the Doyle $v$. Ireland case. In that judgment the Court concluded that there had been no breach of Article $6 \S 3$ (c) of the ECHR, although the total time for interrogation of the suspect in the pre-trial phase was 31 hours and the duration of the contact with a lawyer at that stage of the criminal proceedings was 42 minutes. It is a fact that there was contact with a lawyer, but two circumstances must be highlighted. Firstly, the time of contact with the lawyer was disproportionately short in relation to the

58 The ECtHR judgement (Grand Chamber) of 11 September 2016 in the case of Ibrahim and Others $v$. the United Kingdom application no. 50541/08, 50571/08, 50573/08 and 40351/09, § 145.

59 The ECtHR judgment of 27 April 2017 in the case of Zherdev v. Ukraine application no. 34015/07 § 161-169.

60 See, the ECtHR judgment of 24 May 2019 in the case of Doyle v. Ireland, application no. 51979/17, http://hudoc.echr.coe.int/eng?i=001-193083. 
total length of the several interrogations and it took place before and never during the interrogations. The question of whether it is possible to provide effective legal assistance in such a short period of time should be considered to be rhetorical ${ }^{61}$. One must agree with the critical view of this judgment, which was expressed in a dissenting opinion to the judgment in the Doyle v. Ireland case by judge Ganna Yudkivska. She stated that in that case, not only is it impossible to speak (regardless of the reasons for such a duration of the contacts) of provision of any effective legal assistance, but "in principle the circumstances constituted a complete mockery of legal assistance."

The Doyle v. Ireland case involved factual circumstances similar to the Salduz case, in which the applicant's restricted access to a lawyer arose from a systemic, mandatory, and general restriction of suspects' access to a lawyer in the respondent state's national law. Such a restriction was determined to have irreparably prejudiced the proceedings and thereby constituted a violation of Article $6 \S 1$ and $\S 3$ (c) of the Convention. This case thus illustrates that the Court has made a dramatic U-turn from one of its most progressive judgments, the Salduz case, with its unequivocal prohibition of any blanket restriction on defense rights. The cases presented above demonstrate that a mere violation of the right to contact a counsel does not automatically give rise to a finding of unfairness of the pending proceedings. Such a conclusion can be reached only after it has been established that the conduct as a whole violated the standards arising under Article $6 \S 1$ and § 3 (c) of the Convention. The vagueness of the criteria set out in the Ibrahim and Others case not only makes the jurisprudence of the ECHR far from consistent, but also undermines the rights of the defense and the fairness of the proceedings. Those cases in which, in the absence of a counsel, evidence was admittedly obtained, but was not incriminating, do not appear to be

61 In her dissenting opinion, ECtHR judge Ganna Yudkivska raises further questions: Did the length of contact between the suspect and the lawyer allow for consideration of different defense strategies? Can we allege that a thorough discussion of the applicant's previous interview and preparation for the subsequent one took place each time? It is noteworthy that even during the applicant's crucial 15th interview, prior to making his confession, his communication with his solicitor lasted for only 4 minutes. More information can be found in the ECtHR judgment of 24 May 2019 in the case of Doyle v. Ireland, application no. 51979/17. 
controversial. Of concern are those cases where incriminating evidence was obtained in the absence of a counsel and the ECtHR did not find a violation of the general fairness of the proceedings.

\section{Conclusion}

The case law of the ECtHR sets the standard of protection of rights and freedoms in the territory of those Member States of the Council of Europe that have ratified the Convention for the Protection of Human Rights and Fundamental Freedoms of 1950. The analysis carried out showed the clear evaluation of the case law of the ECtHR in relation to the standard of access of a suspected offender to an advocate at the initial stage of criminal prosecution. The first breakthrough was the judgment in the Salduz case, which defined the scope of the right to lawyer and the fairness of the proceedings. First, suspects must be able to enter into contact with a lawyer from the time when they are taken into custody. In particular, this possibility should exist before the suspect is questioned. Second, suspects have the right to the physical presence of an attorney during initial police interrogation. This opportunity should also exist when they are questioned in the subsequent pre-trial proceedings. And third, it is forbidden to use incriminating statements obtained during an interrogation held in the absence of a lawyer.

The standard of access to a lawyer adopted in the Salduz and postSaladuz case-law increased the protection of a defendant and strengthen his/her position in the criminal proceedings, building up clear European standard of access to a lawyer. This standard was also beneficial to the adversarial model of criminal procedure. It forced the prosecutorial organs to find convincing evidence of guilt instead of simply relying on selfincriminating statements of a suspect provided without prior consultation with a lawyer. It appeared that the judgment in the Salduz case, which was a Strasbourg equivalent of the US Supreme Court's 1963 judgment in the Miranda $v$. Arizona case, would become a permanent part of the case law of the ECtHR ${ }^{62}$. Unfortunately, in the subsequent case-law the Court

62 WEISSELBERG, D. Charles. Exporting and importing Miranda. Boston University Law Review, v. 97, 2017, s. 1258-1279. 
decided to water down the strict approach applied in Salduz case. After 8 years of the Salduz doctrine, the Court took a significant step backwards in 2016 with its judgment in the Ibrahim and Others case. It withdrew from the previous assumption that the absence of reasonable grounds for restricting access to a lawyer automatically results in a violation of the right to a fair trial. Instead, the ECtHR adopted an open and imprecise list of failings that should be taken into account when assessing the fairness of the criminal proceedings as a whole. This approach prevents the formulation of clear country-specific guidelines on how to ensure effective access to a lawyer for suspects, but also how to ensure the fairness of a criminal trial at an early stage of criminal procedure.

\section{REFERENCES}

ARNARDÓTTIR, Oddný Mjöll. Res Interpretata, Erga Omnes Effect and the Role of the Margin of Appreciation in Giving Domestic Effect to the Judgments of the European Court of Human Rights. European Journal of International Law, v. 28, n. 3, p. 819-843, 2017, https://doi.org/10.1093/ejil/chx045

BACHMAIER WINTER, Lorena; THAMAN, C. Stephan. A Comparative View of the Right to Counsel and the Protection of Attorney-Client Communications. In: BACHMAIER WINTER, Lorena; THAMAN, C. Stephen; LYNN, Veronica (eds.). The Right to Counsel and the Protection of Attorney-Client Privilege in Criminal Proceedings. A Comparative View. Springer International Publishing, 2020. https://doi.org/10.1007/978-3-030-43123-5_2

BEIJER, Annemarieke. False confessions during police interrogations and measures to prevent them. European Journal of Crime, Criminal Law \& Criminal Justice, n. 18, p. 311-348, 2010, https://doi.org/10.1163/157181710x12816005399159

BERGER, Mark. Self-Incrimination and the European Court of Human Rights: Procedural Issues in the Enforcement of the Right to Silence. European Human Rights Law Review. vol. 5, p. 514-533, 2007.

BLACKBURN, Robert; POLAKIEWICZ, Jörg (eds). Fundamental rights in Europe: the European Convention on Human Rights and its member states, 1950-2000, Oxford, Oxford University Press, 2001.

BODNAR, Adam. Res Interpretata: The Legal Effect of the European Court of Human Rights Judgments for Other States Than Those Which Were Party to 
the Proceedings. In: HAECK, Yves; BREMS, Eva (eds.). Human Rights and Civil Liberties in the 21st Century, Springer Netherlands, 2014, http://dx.doi. org/10.1007/978-94-007-7599-2_10

CELIKSOY, Ergul. Ibrahim and Others v. UK: Watering down the Salduz principles? New Journal of European Criminal Law, v. 9, n. 2, p. 229-246, 2019, https:// doi.org/10.1177/2032284418778149

CELIKSOY, Ergul. Overruling 'the Salduz Doctrine' in Beuze v Belgium: The ECtHR's further retreat from the Salduz principles on the right to access to lawyer. New Journal of European Criminal Law, v. 10, n. 4, p. 342-362, 2019, https://doi. org/10.1177/2032284419879228

CZERNIKA, Dominika. Europeski Przegląd Sądowy, nr 9, p. Prawo podejrzanego do kontaktu z adwokatem (art. 6 ust. 3 lit. c EKPCz) w orzecznictwie Europejskiego Trybunału Praw Człowieka, p. 28-39, 2017.

DZIERŻANOWSKA, Joanna. Access to a Lawyer for a Suspect at Early Stage of Criminal Proceedings and Its Participation in Investigative Acts. Review of European and Comparative Law, v. 41, n. 2, p. 109-127, 2020, https://doi.org/10.31743/ recl.6153

GERARDS, Janneke; FLEUREN, Josepf (eds.), Implementation of the European Convention on Human Rights and of the judgments of the ECtHR in national case law, Cambridge-Antwerp-Portland, Intersentia, 2014.

GIANNOULOPOULOS, Dimitrios. Strasbourg Jurisprudence, Law Reform and Comparative Law: A Tale of the Right to Custodial Legal Assistance in Five Countries. Human Rights Law Review, v. 16, n. 1, p. 103-129, 2016, https://doi. org/10.1093/hrlr/ngv039

GIANNOULOPOULOS, Dimitrios. Improperly Obtained Evidence in Anglo-American and Continental Law. Oxford: Hart Publishing, 2019.

GINTER, Jaan; SOO, Anneli. The Right of the Suspect to Counsel in Pre-trial Criminal Proceedings, Its Content, and the Extent of Application. Juridica International, v. XIX, p. 170-178, 2012.

GORDON, Van Kessel. European Perspectives on the Accused as a Source of Testimonial Evidence. West Virginia Law Review, vol. 100, p. 799-845, 1999.

GOSS Ryan, Out of Many, One? Strasbourg's Ibrahim decision on Article 6, The Modern Law Review, v. 80, 6, p. 1137-1150, 2017, https://doi.org/10.1111/1468-2230.12305 
GRABENWARTER, Christoph. European Convention on Human Rights. Commentary. München: C. H. Beck; Oxford: Hard; Baden-Baden: Nomos; Basel: Helbing Lichtenhahn Verlag, 2014.

HARRIS, J. David; O'BOYLE, Michael; WARBRICK, Chris. Law of the European Convention on Human Rights. London, Dublin, Edinburgh: Butterworths, 1995.

HASSEMER, Winfried. Human Dignity in the Criminal Process: The Example of the Truth-Finding. Israel Law Review, v. 44, n. 1-2, p. 185-198, 2011, https://doi. org/10.1017/s0021223700001011

HAECK, Yves; BREMS, Eva (eds.). Human Rights and Civil Liberties in the 21st Century, Springer Netherlands, 2014.

HÖRNLE, Tatjana; KREMNITZER, Mordechai. Human dignity as a protected interest in criminal law, Israel Law Review, v. 44, p. 143-167, 2011, https://doi. org/10.1017/S0021223700000996

JACKSON, D. John. Common Law Evidence and the Common Law of Human Rights: Towards a Harmonic Convergence? Towards a Harmonic Convergence?. William \& Mary Bill of Rights Journal, v. 27, n. 3, p. 689-715, 2019.

JACKSON, D. John, Responses to Salduz: procedural tradition, change and the need for effective defence. Modern Law Review, v. 76, n. 6, p. 987-1018, 2016, https://doi.org/10.1111/1468-2230.12227

JASIŃSKI, Wojciech: Dostęp osoby oskarżonej o popełnienie czynu zagrożonego karą do adwokata na wstępnym etapie ścigania karnego - standard strasburski. Europejski Przegląd Sądowy, n. 1, p. 25-28, 2019.

LAGODNY, Otto. Human Dignity and Its Impact on German Substantive Criminal Law and Criminal Procedure. Israel Law Review, v. 33, n. 3, p. 575-591, 1999, https://doi.org/10.1017/s002122370001606x

LEVERICK, Leverick, Fiona. The Right to Legal Assistance During Detention. Edinburgh Law Review, v. 15, p. 352-380, 2011, https://doi.org/10.3366/elr.2011.0057

NEUMANN, Ulfrid. Materielle und prozedurale Gerechtigkeit im Strafverfahren. Zeitschrift für die gesamte Strafrechtswissenschaft, v. 101, n. 1, p. 52-74, 1989, https://doi.org/10.1515/zstw.1989.101.1.52

OGORODOVA, Anna; SPRONKEN, Taru. Legal Advice in Police Custody: From Europe to a Local Police Station. Erasmus Law Review, v. 4, p. 191-205, 2014, https://doi.org/10.5553/elr.000021 
OWUSU-BEMPAH, Abenaa, Silence in suspicious circumstances. Criminal Law Review, n. 2, p. 126-135, 2014.

PERONI, Lourdes; TIMMER, Alexandra. Vulnerable Groups. the Promise of an Emergent Concept in European Human Rights Convention Law. International Journal of Constitutional Law, n. 11, 1056-1085, 2013, https://doi.org/10.1093/ icon/mot042

RESS, Georg. The effects of decisions and judgments of the European Court of Human Rights in the domestic legal order. Texas International Law Journal, vol. 40, 2005.

SAKOWICZ, Andrzej. Standard of the protection of the right to silence applicable to persons examined as witnesses in the light of the European Court of Human Rights case law. Ius Novum, n. 2, p. 120-136, 2018, https://doi.org/10.26399/ iusnovum.v12.2.2018.19/a.sakowicz

SCHABAS, A. William. The European Convention on Human Rights. A Commentary. Oxford: Oxford University Press, 2015.

SCHLEGEL, Stephan; WOHLERS, Wolfgang. Der »Anwalt der ersten Stunde« in der Schweiz. Strafverteidiger, n. 5, p. 307-318, 2012.

SCHWEIGER, F. Theresa. Prozedurales Strafrecht. Baden-Baden: Nomos, 2018.

SKORUPKA, Jerzy. O sprawiedliwości procesu karnego. Warszawa: WoltersKluwer, 2013.

SOO, Anneli. Divergence of European Union and Strasbourg Standards on Defence Rights in Criminal Proceedings? Ibrahim and the others v. the uk (13th of September 2016). European Journal of Crime, Criminal Law and Criminal Justice, v.25, n. 4, p. 327-346, 2017, https://doi.org/10.1163/15718174-02504002

SUXBERGER, Antonio H. G.; MELLO, Gabriela S. J. V. A voluntariedade da colaboração premiada e sua relação com a prisão processual do colaborador. Revista Brasileira de Direito Processual Penal, Porto Alegre, vol. 3, n. 1, p. 189-224, 2017. https://doi.org/10.22197/rbdpp.v3i1.40

THAMAN, C. Stephan; LYNN, Veronica (eds.). The Right to Counsel and the Protection of Attorney-Client Privilege in Criminal Proceedings. A Comparative View. Springer International Publishing, 2020.

TRECHSEL, Stefan. Human Rights in Criminal Proceedings. Oxford New York: Oxford University Press: 2005. 
TIMMER, Alexandra. A Quiet Revolution: Vulnerability in the European Court of Human Rights. In: FINEMAN, Albertson; GREAR, Anna (eds.). Vulnerability: Reflections on a New Ethical Foundation for Law and Politics, Farnham: Ashgate, 2013.

VAN DE LAAR, Tom; DE GRAAFF, Regien. Salduz and Miranda: Is the US Supreme Court Pointing the Way?. European Human Rights Law Review, v. 3, p. 304-317, 2011.

WALTOŚ, Stanisław; HOFMAŃSKI, Piotr. Proces karny. Zarys system. Warszawa: WoltersKluwer, 2020.

WĄSEK-WIADERER, Małgorzata: Model zakazów dowodowych z perspektywy Konwencji i orzecznictwa ETPCz. En: SKORUPKA, Jerzy; DROZD, Anna (eds.). Nowe spojrzenie na model zakazów dowodowych w procesie karnym, Warszawa: C. H. Beck, 2015.

WEIGEND, Thomas. Is the Criminal Process about Truth?: A German Perspective. Harvard Journal of Law \& Public Policy, v. 26, n. 1, p. 157-193, 2003.

WEIGEND, Thomas; GHANAYIM, Khalid. Human Dignity in Criminal Procedure: A Comparative Overview of Israeli and German Law. Israel Law Review, v. 44, n. 1-2, p. 198-228, 2011, https://doi.org/10.1017/s0021223700001023

\section{Additional information and author's declarations (scientific integrity)}

Conflict of interest declaration: the author confirms that there are no conflicts of interest in conducting this research and writing this article.

Declaration of authorship: all and only researchers who comply the authorship requirements of this article are listed as authors; all coauthors are fully responsible for this work in its entirety.

Declaration of originality: the author assures that the text here published has not been previously published in any other resource and that future republication will only take place with the express indication of the reference of this original publication; he also attests that there is no third party plagiarism or self-plagiarism. 


\section{Editorial process dates}

(http://www.ibraspp.com.br/revista/index.php/RBDPP/about/editorialPolicies)

- Submission: 14/12/2020

- Desk review and plagiarism check: 20/12/2020

- Review 1: 05/01/2021

- Review 2: 10/01/2021

- Editorial decision: 18/02/2021

- Resubmission: 12/05/2021

- Review 3: 26/06/2021

- Review 4: 21/07/2021

- Preliminary editorial decision: $18 / 08 / 2021$

- Correction round return: 02/09/2021

- Preliminary editorial decision 2: 20/09/2021

- Correction round return 2: 20/09/2021

- Final editorial decision: 02/10/2021

\section{Editorial team}

- Editor-in-chief: 1 (VGV)

- Reviewers: 4

\section{HOW TO CITE (ABNT BRAZIL):}

SAKOWICZ, Andrzej. Suspect's access to a lawyer at an early stage of criminal proceedings in view the case-law of the European Court of Human Rights. Revista Brasileira de Direito Processual Penal, vol. 7, n. 3, p. 1979-2014, set./dez. 2021. https://doi.org/10.22197/rbdpp.v7i3.565

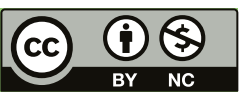

Esta obra está licenciada com uma Licença Creative Commons Atribuição-NãoComercial 4.0 Internacional. 